\title{
Student Problem Assessment (SPA) in the Covid-19 Condition in terms of 10 Sub Areas of Life Problems (10-ALP)
}

\author{
Agus Supriyanto, Purwadi*, Wahyu N. E. Saputra, Irvan B. Handaka, Muya Barida, Dian Ari Widyastuti, \\ Agungbudiprabowo, Siti Muyana, Amien Wahyudi, Mita D. Sari \\ Jalan Kolektor Ring Road Selatan, Tamanan Banguntapan Bantul Yogyakarta, Indonesia
}

\begin{abstract}
Student problems in the Covid-19 condition are very complex and urgent in the needs of the Covid-19 pandemic and after Covid-19. School counsellors have the competence to identify through assessment. However, not all reviews can analyze students' problems comprehensively. This study focuses on assessing student problems that can diagnose the condition of students from the personal, social, academic, and career fields. The research method uses a mixed-method through qualitative data supported by quantitative data. The research targets were students, then tested the validity and reliability for students $\mathrm{N}=929$. The results of data analysis describe ten students' problems from the personal, social, learning, and career fields with valid and reliable items. The results of item validity are 49 accurate statement items or corrected item-total correlation $>0.1161$, while one thing is invalid with 0.936 reliability or very high criteria. School counsellors can use assessment of student problems in analyzing student problems and needs. The results of the evaluation can be used for guidance and counselling plans by school counsellors.
\end{abstract}

Keywords : COVID-19, Problematization, Student Asessment.

\section{INTRODUCTION}

The covid-19 pandemic hit the whole world (Zizek, 2020) and hasn't ended until 2021 despite declining (Adjemian et al., 2021), And then well as the need for policies in education areas within 3-5 years related to Covid-19 (Skegg et al., 2021). The total of positive suspects, deaths and hospitalized patients continues to grow (Lurie et al., 2020). The current COVID-19 pandemic has impacted aspects of life, especially in the field of education. The Covid-19 pandemic has also affected the learning system as well as the useful lives of students. The learning process in this world has disruption by the Covid19 pandemic, which has not stopped in 2021, and the whole country has adapted.

The Covid-19 pandemic has had a universal impact on elementary, secondary and higher education levels. Students and students are most affected by the educational process itself, especially online learning or blended learning. Students feel concerned about their careers, professional studies, their future and experience boredom, anxiety, and frustration in daily life (Aristovnik et al., 2020; Saputra, Alhadi, et al., 2021; Saputra, Mappiare-AT, et al., 2021). The Covid-19 pandemic has had an evil effect on students' lives in India, despite the use of technology. Meanwhile, in the Philippines, applying the new normal situation affects future crises in education (Tria, 2020). Indonesian students also feel a lot of stress due to distance learning management that is not carried out comprehensively and is less able to organize online learning activities (Churiyah et al., 2020; Purwadi et al., 2021; Yusuf, 2021).

There is no comprehensive identification yet, so school counsellors require a more in-depth identification of all student phenomena and problems during the COVID-19 pandemic. The study results stated that stress, anxiety, and depressive thoughts among students caused fear and concern about health, difficulty in concentrating, disturbed sleep patterns, and decreased social interaction due to physical distance (Son et al., 2020). The covid-19 pandemic also harms the mental health of students and college students (Savage et al., 2020), although the online learning process has been implemented (Hasan \& Bao, 2020). The emergence of anti-social behaviour conditions, cheating on exams and having premarital sex in students in Cameroon (Bobga, 2016). Student problems during the COVID-19 pandemic and online learning need more in-depth identification by school counsellors to determine and implement appropriate guidance and counselling services for students. The provision was of guidance and counselling services essential in various conditions.

\section{Corresponding Author e-mail: Purwadi@psy.uad.ac.id} https://orcid.org/0000-0001-5166-7583,

How to cite this article: Supriyanto A, Purwadi, Saputra WNE, Handaka IB, Barida M, Widyastuti DA, Agungbudiprabowo, Muyana S, Wahyudi A, Sari MD (2022). Student Problem Assessment (SPA) in the Covid-19 Condition in terms of 10 Sub Areas of Life Problems (10-ALP). Pegem Journal of Education and Instruction, Vol. 12, No. 1, 2022, 199-206

Source of support: Nil

Conflict of interest: None.

DOI: 10.47750/pegegog.12.01.20

Received: 09.09.2021

Accepted: 12.12.2021 Publication: 01.01.2022 
Guidance and counselling assessments by school counsellors have not adjusted to student conditions during the Covid-19 pandemic. Review for students can use online to find out the needs of students. Evaluation measure of students with the Covid-19 pandemic crucial, as does learning adaptation and assessment through technology (Khan \& Jawaid, 2020). Creating a student problem-based needs assessment during the COVID-19 pandemic is urgently required by guidance and counselling teachers or school counsellors. Non-test checklist problem assessment to uncover student problems (Arjanto, 2015) becomes the basic premise. Can implement Implementation of student needs assessment through asynchronous media and synchronous media (Supriyanto et al., 2020; Nadiahan \& Cabauatan, 2021).

The student's condition during the covid-19 pandemic will develop a problem assessment with ten problem areas. The first is a matter of personal areas related to health, financial life circumstances, personal relationships, recreation and hobbies, and religion and morals. Both social problems are related to young people's lives, family life, social and emotional connections. The third is a career problem about the future and educational goals. Finally, there are academic issues related to adjustment to online learning. The assessment aims to obtain student data in-depth and accurately about student problems (Wahyuni, 2016). The purpose of this study is to find valid and reliable items regarding student problem assessment (SPA) during the covid-19 pandemic to use them to design synchronous and asynchronous guidance and counselling services.

\section{Literature Review}

\section{Student Problem Assessment (SPA) During the Covid-19 Pandemic and Post Pandemic}

The problems experienced by every human being have a deep definition. One of the people who have problems with the impact of covid-19 in education is students. The description of a problem is a lack of knowledge or knowledge framework that creates a psychological crisis in life (Muthukrishna \& Henrich, 2019). These conditions reveal that every human being has a problem with a different point of view on conditions. Another definition confirms that a problem from a psychological perspective is a condition that requires additional sacrifice by proposing a solution and then drawing out some good implications or expected outcomes for understanding supererogation and letting go of bad conditions (Horton, 2017). In this condition, every student experiences problems in practical daily life. The student's problem is the lack of a knowledge framework that creates a psychological crisis and requires additional effort to find and implement solutions and get the best results.

Every student experiencing a problem situation will take the task to understand the situation and engage in some activities with the involvement of reason (Mason, 2016). One of the problems experienced by students is the adequate daily living conditions during the covid-19 pandemic. So students experiencing problems during the covid-19 pandemic regarding practical everyday life will immediately understand the situation and requirements to find and implement the best solution for themselves-optimality for self to crisis problem as the context of survival theory (Pfeiffer \& Bayen, 2019).

\section{Guidance and Counseling Assessment}

The provision of guidance and counselling services is crucial for students (Alemu, 2013). The primary basis of guidance and counselling services is student needs measured through guidance and counselling assessment (Dogar et al., 2011). Guidance and counselling assessment is a sensitive and contextual assessment to guide intervention and make meaning of students' needs (Cardoso \& Sales, 2019). Guidance and counselling assessments describe the current quality and predict future behaviour, provide guidance and counselling service information, define intervention methods, evaluate progress, and screen for students' unique needs (Oakland \& Iliescu, 2016). The conclusion of the guidance and counselling assessment is a measuring tool or assessment to determine student needs so that school counsellors can choose the proper intervention with guidance and counselling services.

The implementation of the guidance and counselling assessment to students according to students' actual conditions. The review provides new information about students that can guide further work (Cornell et al., 2018) by counsellors to develop guidance and counselling service practices. The assessment results from open opportunities for appropriate interventions in the future in guidance and counselling interventions for positive living (Di Fabio \& Bucci, 2016).

\section{Ten Problem Areas About Student Life}

Problems experienced by students can describe into ten problem areas. Student problems include health, finance, psychological, social relationships, personal and emotional relationships, youth, family, moral and religious relationships, future career adaptation, curriculum and teaching, and academic problems (Alavi \& Mansor, 2011). The ten main essential problem areas know the conditions related to students' daily lives. Ten regions of student problems during the Covid-19 pandemic are also associated with health protocols, social distancing, and digital learning (Abidah et al., 2020).

\section{Methods}

\section{Research Design}

Mix method research in this study combines qualitative research and quantitative research. The research examines ten 
concept problem areas through primary sources from books and relevant scientific articles. The ten problem areas cover four main areas in personal, social, academic, and career. Problems include health issues, financial situation issues, personal relationship issues, recreational and hobby issues, and religious and moral issues. The social field is related to young people's life problems, family problems, social and emotional relationship problems. A career field that deals with future issues and educational goals. The academic field is related to the problem of adapting to online learning and school climate (Saputra et al., 2020).

\section{Participants}

In addition, researchers conducted a case study of 929 subjects about students' conditions in Indonesia related to these ten problem areas. The researchers compiled a grid and assessment items related to 10 problem areas in the conceptual and case studies. The results of the assessment items were tested on 929 subjects under new normal learning conditions during the COVID-19 pandemic and analyzed through statistical tests.

\section{Data Collection Tools}

The instruments are designed according to conditions during the Covid-19 pandemic or post Covid-19 pandemic. Quantitative analysis through a trial process to determine the validity and reliability of items from 10 problem areas experienced by students.

\section{Data Collection}

In the first stage, this research seeks to construct theory and instrument grids. Second, this study determines the test subjects to determine the level of validity and reliability of the instrument. Furthermore, the third, this study conducted data analysis to determine the results of the validity and reliability of the instrument.

\section{Data Analysis}

Analysis case study through data reduction patterns to the conclusion. Validity from SPA through product-moment analysis, and then SPA reliability through alpha-cronbanch analysis. The results of the Student Problem Assessment (SPA) research can use by guidance and counselling teachers, students, school counsellors, researchers, practitioners, and lecturers to find out student problems during the COVID-19 pandemic and develop guidance and counselling programs/ services.

\section{FINDINGS}

This study found that the Student Problem Assessment (SPA) had ten sub-problems: health, financial life circumstances, personal relationships, recreation and hobbies, religious

Table 1: Student Problems Assessment Grid

\begin{tabular}{lllll}
\hline Guidance and counseling field & Problem Area & Valid & Invalid & N \\
\hline Personal & Health & 5 & 0 & 0 \\
& Economic Life & 5 & 0 & 5 \\
& Religion and Morals & 5 & 1 & 5 \\
& Recreation and Hobbies & 4 & 5 & 5 \\
Social & Social and Emotional & 5 & 0 & 5 \\
& Youth Relationship & 5 & 0 & 5 \\
Academik & Adaptation to online learning & 5 & 0 & 5 \\
& Difficulty Learning & 5 & 0 & 5 \\
Carier & Online Learning Curriculum & 6 & 5 & 5 \\
Totally & Future and Ideals of Education & 5 & 5 & 5 \\
\hline
\end{tabular}

Table 2. The Validity of the SPA in the personal sub variable and Health Area

\begin{tabular}{llll}
\hline No & Corrected Item-Total Correlation & Item & Valid / Invalid \\
\hline A1 & 0.376 & My appetite has disruption due to the Covid-19 outbreak. & Valid \\
A2 & 0.189 & Feeling uneasy when leaving the house. & Valid \\
A3 & 0.390 & My health disrupted due to the covid-19 pandemic. & Valid \\
A4 & 0.406 & Lack of or not being able to sleep since the covid-19 pandemic. & Valid \\
A5 & 0.390 & Food does not meet health requirements. & Valid \\
\hline
\end{tabular}


and moral issues, young people's lives, family life, social and emotional relationships, future and aspirations, educational ideas, curriculum and education, as well as adjustments to online learning. All problem areas are internalizing in the four guidance and counselling areas covering personal, social, academic, and career with the SPA lattice.

The study results found a SPA with 50 valid statement items and one invalid statement item. Each problem area has appropriate statement items for measuring student problems during the covid-19 pandemic conditions. The value of the validity of the assessment item is feasible to use if the corrected item-total correlation $>0.1161$ with the total of test subjects is $\mathrm{N}=929$. Below is the data for each problem area.

The field of health issues as a personal matter has five statements. All statements are valid with validity $>0.1161$. The field of health problems needs to be assessed by guidance and counselling teachers or psychologists to determine students' health conditions in the Covid-19 pandemic or post-covid-19 preparations.

The field of economics as a personal matter has five statements. All statements are valid with validity $>0.1161$. The field of health problems needs to be studied by guidance and counselling teachers or psychologists to determine the economic conditions of students that impact students' psychology during the Covid-19 pandemic or post-Covid-19 preparations.
The field of religion and morals as a personal matter has five statements. All statements are valid with validity $>0.1161$. The field of religious and moral issues needs to be studied by guidance and counselling teachers or psychologists to find out the religious and moral conditions of students that impact students' daily lives with themselves, others, and God during the Covid-19 pandemic or post-Covid-19 preparations.

The field of recreation and hobbies as a personal matter has five statements. One invalid statement with validity $<0.1161$ and four valid statements with validity $>0.1161$. The field of recreation and hobbies is because students are not optimal in channelling their hobbies and are less able to do recreation. This condition needs to be studied by guidance and counselling teachers or psychologists to determine students' psychological conditions that impact burnout conditions or student stress in daily life during the Covid-19 pandemic or post-Covid-19 preparations.

The field of social and emotional problems as social problems has five statements. All statements are valid with validity $>0.1161$. The field of social and emotional problems is because students are not optimal in channelling themselves as social beings and interacting with others because of selflimitation. This condition needs to be studied by guidance and counselling teachers or psychologists to determine the psychological and social conditions of students in daily life during the Covid-19 pandemic or post-Covid-19 preparations.

Table 3: Validity of the SPA in the personal sub variable and Economic Life are

\begin{tabular}{llll}
\hline No & Corrected Item-Total Correlation & Item & Valid / Invalid \\
\hline B1 & 0.427 & Inability to buy internet quota to study online. & Valid \\
B2 & 0.249 & I don't have a cellphone/laptop to study online. & Valid \\
B3 & 0.466 & Signal difficulties that support learning. & Valid \\
B4 & 0.437 & The signal where I live doesn't support it. & Valid \\
B5 & 0.344 & I'm also looking for income for school fees. & Valid \\
\hline
\end{tabular}

Table 4: The validity of the SPA in personal sub variable and Religion and Morals are

\begin{tabular}{lllll}
\hline No & Corrected Item-Total Correlation & Item & Valid / Invalid \\
\hline C1 & 0.421 & Lack of feeling the benefits of religion during the covid-19 pandemic or later. & Valid \\
C2 & 0.421 & I can't do worship at home during the covid-19 pandemic or after. & Valid \\
C3 & 0.379 & I violated the rules of the covid-19 protocol when you were outside the house. & Valid \\
C4 & 0.426 & I am getting lazy to worship at home during the covid-19 pandemic or after. & Valid \\
C5 & 0.425 & Lack of feeling the benefits of religion during the covid-19 pandemic or after. & Valid \\
\hline
\end{tabular}

Table 5: The validity of the SPA in the personal sub variable and Recreation and Hobbies area

\begin{tabular}{lllll}
\hline No & Corrected Item-Total Correlation & Item & Valid / Invalid \\
\hline D1 & 0.339 & My desire for recreation has blocking due to the covid-19 pandemic. & Valid & Invalid \\
D2 & 0.072 & During the holidays during the covid-19 pandemic, I have to study. & Valid & Valid \\
D3 & 0.377 & Running out of time due to watching TV due to being at home constantly. & Valid \\
D4 & 0.441 & During holidays, when I get bored if I continue to help my parents. & When I'm on holiday, I'm not happy at home. \\
D5 & 0.447 & &
\end{tabular}


The field of youth relations as a social problem has five statements. All statements are valid with validity $>0.1161$. Children and adolescents own the problem area of youth relations because students are not optimal in channelling themselves as social beings and interacting with peers. This condition needs to be studied by guidance and counselling teachers or psychologists to determine the psychological and social conditions of students in daily life during the Covid-19 pandemic or post-Covid-19 preparations.

The problem area of adaptation in online learning as an academic problem has five statements. All statements are valid with validity $>0.1161$. Areas of adaptation problems with online learning because not all have internet access in online learning. This condition needs to be studied by guidance and counselling teachers or psychologists to determine the psychological condition and academic development of students in daily life during the Covid-19 pandemic or post-Covid-19 preparations.

The problem area of learning difficulties as an academic problem has five statements. All statements are valid with validity $>0.1161$. The problem of learning difficulties is limited access to learning and self-restriction due to the Covid-19 pandemic in schools. This condition needs to be studied by guidance and counselling teachers or psychologists to determine academic developments as a diagnosis of student learning difficulties in daily life during the Covid-19 pandemic or post-Covid-19 preparations.

The problem area of the online learning curriculum as an academic problem has five statements. All statements are valid with validity $>0.1161$. The field of online learning curriculum is due to school restrictions with online learning curricula. This condition needs to be studied by guidance and counselling teachers or psychologists to determine students' academic development in daily life during the Covid-19 pandemic or post-Covid-19 preparations and other policies related to blended learning.

The future problem area and the ideals of education as a career problem have five statements. All statements are valid with validity $>0.1161$. Future fields and educational aspirations due to students' doubts for future careers and the Covid19 pandemic conditions related to job opportunities. This condition needs to be studied by guidance and counselling teachers or psychologists to motivate students in career planning.

Table 6: The validity of the SPA in the social sub variable and Social and Emotional area

\begin{tabular}{|c|c|c|c|}
\hline No & Corrected Item-Total Correlation & Item & Valid / Invalid \\
\hline E1 & 0.235 & I always felt anxious when meeting other people since the Covid-19 pandemic. & Valid \\
\hline E2 & 0.591 & I feel pessimistic about my learning outcomes when learning online or blended learning. & Valid \\
\hline E3 & 0.595 & I feel insecure when undergoing online education or blended learning. & Valid \\
\hline E4 & 0.523 & I felt bored during the covid-19 pandemic with online learning. & Valid \\
\hline E5 & 0.274 & During this pandemic, it's hard to hang out with friends. & Valid \\
\hline
\end{tabular}

Table 7: The validity of the SPA in the social sub variable and Youth Relationship

\begin{tabular}{|c|c|c|c|}
\hline No & Corrected Item-Total Correlation & Item & Valid / Invalid \\
\hline F1 & 0.412 & More thinking about love problems than studying. & Valid \\
\hline $\mathrm{F} 2$ & 0.399 & I watch movies about love more often than studying. & Valid \\
\hline F3 & 0.431 & $\begin{array}{l}\text { I violated the rules of the covid- } 19 \text { protocol to go out of the house to meet a female/ } \\
\text { male friend. }\end{array}$ & Valid \\
\hline $\mathrm{F} 4$ & 0.434 & More often daydream thinking about female/male friends. & Valid \\
\hline F5 & 0.403 & $\begin{array}{l}\text { Female/male friends often invite them out of the house even though it's a covid-19 } \\
\text { pandemic. }\end{array}$ & Valid \\
\hline
\end{tabular}

Table 8: The validity of the SPA in the academic sub variable and adaptation to online learning area

\begin{tabular}{llll}
\hline No & Corrected Item-Total Correlation & Item & Valid / Invalid \\
\hline G1 & 0.528 & Feeling unnoticed by the teacher when studying online. & Valid \\
G2 & 0.450 & I never skipped because I overslept. & Valid \\
G3 & 0.500 & Late collection of assignments. & Valid \\
G4 & 0.252 & Unable to participate in extracurricular activities. & Valid \\
G5 & 0.559 & Some lessons that I don't like because it's hard for me to understand. & Valid \\
\hline
\end{tabular}


Table 9: The validity of the SPA in the academic sub variable and Difficulty Learning area

\begin{tabular}{|c|c|c|c|}
\hline No & $\begin{array}{l}\text { Corrected Item-Total } \\
\text { Correlation }\end{array}$ & Item & Valid / Invalid \\
\hline H1 & 0.613 & Due to online learning, I got low marks. & Valid \\
\hline $\mathrm{H} 2$ & 0.618 & I was feeling lazy to read books while studying at home. & Valid \\
\hline H3 & 0.553 & Difficult to catch material and follow online learning. & Valid \\
\hline $\mathrm{H} 4$ & 0.620 & School lessons during the Covid-19 pandemic are too heavy. & Valid \\
\hline H5 & 0.384 & I am often worried when studying online if the internet connection is not stable. & Valid \\
\hline
\end{tabular}

Table 10: The validity of the SPA in the academic sub variable and Online Learning Curriculum area

\begin{tabular}{lllll}
\hline No & $\begin{array}{l}\text { Corrected Item-Total } \\
\text { Correlation }\end{array}$ & Item & Study time is not adequate during the Covid-19 pandemic or blended learning. & Valid / Invalid \\
\hline I1 & 0.562 & Always copy the work/assignments of classmates because they are lazy to study. & Valid & Valid \\
I2 & 0.492 & It is challenging to manage time to do tasks during the covid-19 pandemic. & Valid \\
I3 & 0.624 & It's hard to concentrate on studying because you're distracted by a busy house. & Valid \\
I4 & 0.552 & Rarely study and rarely make material summaries because they are lazy to learn. & Valid \\
I5 & 0.535 & It isn't easy to understand the lessons during distance learning. & Valid & \\
I6 & 0.638 & &
\end{tabular}

Table 11: The validity of the SPA in the carier sub variable and Future and Ideals of Education area

\begin{tabular}{|c|c|c|c|}
\hline No & $\begin{array}{l}\text { Corrected Item-Total } \\
\text { Correlation }\end{array}$ & Item & Valid / Invalid \\
\hline $\mathrm{J} 1$ & 0.624 & I can't hone or develop my skills. & Valid \\
\hline $\mathrm{J} 2$ & 0.605 & $\begin{array}{l}\text { After graduating from school, I worried that I could not continue my studies because I felt I } \\
\text { lacked learning. }\end{array}$ & Valid \\
\hline $\mathrm{J} 3$ & 0.638 & $\begin{array}{l}\text { Pessimistic about the future because it is related to the difficulty of understanding lessons during } \\
\text { a pandemic like this }\end{array}$ & Valid \\
\hline $\mathrm{J} 4$ & 0.605 & $\begin{array}{l}\text { I was worried about not standing alone due to a lack of face-to-face guidance from teachers due } \\
\text { to online learning or blended learning. }\end{array}$ & Valid \\
\hline $\mathrm{J} 5$ & 0.586 & $\begin{array}{l}\text { It's complex or challenging to determine which school to continue because of being pessimistic } \\
\text { about the current situation. }\end{array}$ & Valid \\
\hline
\end{tabular}

Table 12: Reliability of SPA Instrumen Instruments

\begin{tabular}{lll}
\hline Cronbach's Alpha & $\begin{array}{l}\text { Cronbach's Alpha Based on } \\
\text { Standardized Items }\end{array}$ & Nof Items \\
\hline .936 & .936 & 51 \\
\hline
\end{tabular}

\section{SPA is reliable for use to students by school counsellor}

SPA as an instrument that measures student problems in the Covid-19 pandemic is very feasible to use. Feasibility of statistical data that the reliability of the SPA is 0.936 . The findings of this study are that SPA is reliable or suitable for students, by school counsellors to find out student problems and analyze the needs of student guidance and counselling services in schools.

\section{Discussions}

Every student in the Covid-19 pandemic has academic problems that impact social, personal, and future career conditions. Facts related to social self-limitation cause stress
(Flaudias et al., 2020) and create psychological problems (Haworth et al., 2020). Psychological problems occur in students and parents or families, especially in poor economic groups. Financial constraints raise students' issues related to academic situations and stress in students' careers. Using smartphones in online learning also causes students' addiction to social media and social problems (Hosen et al., 2021). SPA has advantages in measuring student problems from various issues during the Covid-19 pandemic and conditions after the Covid-19 pandemic.

The ten problem topics in the Student Problem Assessment (SPA) have included all elements of student life from personal, social, academic, and career. Students have a variety of tasks and jobs during the Covid-19 pandemic in the education sector (Daniel, 2020), so SPA can comprehensively measure the elements of student life. The study results stated that the covid-19 pandemic affected student learning online or blended learning with various student health problems and economic losses from online education, then problems in 


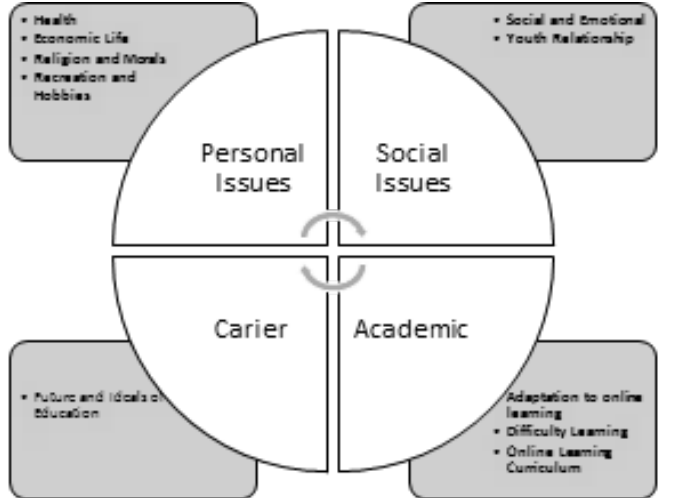

Fig. 1: Four Areas of Student Problems with Sub-Areas in SPA

online learning and blended learning (Wahid et al., 2020). The post-Covid-19 pandemic has also raised economic and social issues due to the Covid-19 pandemic (Nolan, 2021). However, SPA has advantages in comprehensively measuring the dimensions of health and economics in the student's field and the online learning process with its difficulties and curriculum in learning. SPA also counts students' problems in the career field as a life plan.

SAP is an instrument for counsellors to identify the condition of students in the Covid-19 pandemic and postCovid-19 pandemic conditions. The counsellor's ability to understand himself and see a problem is a school counsellor's professional competence. SPA with four fields and ten subfields of student problems is urgent to be applied by school counsellors. School counsellors, practitioners, psychologists, and other academics can use SPA to arrange interventions for students to adapt to the pandemic and post-Covid-19 pandemic conditions immediately.

\section{Conclusion}

Student Problem Assessment (SPA) is a student measuring tool that includes personal, social, learning and career fields. SPA has validity and reliability with very high criteria. Forty-nine statements measure students' problems with ten sub-fields. Subareas about health, financial life circumstances, personal relationships, recreation and hobbies, religious and moral issues, young people's lives, family life, social and emotional relationships, future and educational goals, curriculum and education, and the last are adjustment to online learning. School counsellors and psychologists can use the results of the SPA data as a data collection process, then develop a work program for school counsellors in counselling and guidance services in schools.

\section{Limitations and Future Studies}

Student problems assessment (SPA) is limited to identifying needs in the conditions of Covid-19 and post-COVID-19 pandemics. This research is the primary basis for school counsellors to develop guidance and counselling programs. Student problem assessment (SPA) as a basis for recommending appropriate interventions through guidance and counselling services. Guidance and counselling services to students through individual service formats, group services, and classical services. Student Problem Assessment (SPA) can use by guidance and counselling teachers, school counsellors, lecturers, practitioners, students, and researchers to measure student needs.

\section{Acknowledgement}

Thank you to the school leadership for providing the opportunity to develop a student problems assessment during the Covid-19 pandemic. Thank you to the Institute for Research and Community Service for carrying out the research. Thanks also to the students involved and the students involved in the process of collecting research data.

\section{References}

Abidah, A., Hidaayatullaah, H. N., Simamora, R. M., Fehabutar, D., \& Mutakinati, L. (2020). The Impact of Covid-19 to Indonesian Education and Its Relation to the Philosophy of "Merdeka Belajar." Studies in Philosophy of Science and Education, 1(1), 38-49.

Adjemian, J., Hartnett, K. P., Kite-Powell, A., DeVies, J., Azondekon, R., Radhakrishnan, L., van Santen, K. L., \& Rodgers, L. (2021). Update: COVID-19 pandemic-associated changes in emergency department visits-United States, December 2020-January 2021. Morbidity and Mortality Weekly Report, 70(15), 552.

Alavi, M., \& Mansor, S. M. S. (2011). Categories of problems among international students in Universiti Teknologi Malaysia. Procedia-Social and Behavioral Sciences, 30, 1581-1587.

Alemu, Y. (2013). Assessment of the provisions of guidance and counseling services in secondary schools of East Harerge Zone and Hareri Region, Ethiopia. Middle Eastern \& African Journal of Educational Research, 2, 28-37.

Aristovnik, A., Keržič, D., Ravšelj, D., Tomaževič, N., \& Umek, L. (2020). Impacts of the COVID-19 pandemic on life of higher education students: A global perspective. Sustainability, 12(20), 8438.

Arjanto, P. (2015). Identifikasi Masalah Menggunakan Teknik Problem Check-List Pada Mahasiswa Program Studi Bimbingan dan Konseling Universitas Pattimura. JKI (Jurnal Konseling Indonesia), 1(1), 1-13.

Bobga, T.-N. J. (2016). An Appraisal of Effective Provision of Guidance and Counseling Services in Cameroon State Universities: Trends and Challenges. IJHSSE: International Journal of Humanities Social Sciences and Education, 3(9), 75-90.

Cardoso, P., \& Sales, C. M. (2019). Individualized career counseling outcome assessment: A case study using the personal questionnaire. The Career Development Quarterly, 67(1), 21-31.

Churiyah, M., Sholikhan, S., Filianti, F., \& Sakdiyyah, D. A. (2020). Indonesia education readiness conducting distance learning 
in Covid-19 pandemic situation. International Journal of Multicultural and Multireligious Understanding, 7(6), 491-507.

Cornell, D., Maeng, J. L., Burnette, A. G., Jia, Y., Huang, F., Konold, T., Datta, P., Malone, M., \& Meyer, P. (2018). Student threat assessment as a standard school safety practice: Results from a statewide implementation study. School Psychology Quarterly, 33(2), 213.

Daniel, J. (2020). Education and the COVID-19 pandemic. Prospects, 49(1), 91-96.

Di Fabio, A., \& Bucci, O. (2016). Green positive guidance and green positive life counseling for decent work and decent lives: Some empirical results. Frontiers in Psychology, 7, 261.

Dogar, A. H., Azeem, M., Majoka, M. I., Mehmood, A., \& Latif, S. (2011). Need assessment of students' guidance and counseling. British Journal of Arts and Social Sciences, 1(2), 108-124.

Flaudias, V., Iceta, S., Zerhouni, O., Rodgers, R. F., Billieux, J., Llorca, P.-M., Boudesseul, J., De Chazeron, I., Romo, L., \& Maurage, P. (2020). COVID-19 pandemic lockdown and problematic eating behaviors in a student population. Journal of Behavioral Addictions, 9(3), 826-835.

Hasan, N., \& Bao, Y. (2020). Impact of "e-Learning crack-up" perception on psychological distress among college students during COVID-19 pandemic: A mediating role of "fear of academic year loss." Children and Youth Services Review, 118, 105355.

Haworth, A., Fielding, A. L., Marsh, S., Rowshanfarzad, P., Santos, A., Metcalfe, P., \& Franich, R. (2020). Will COVID-19 change the way we teach medical physics post pandemic? Physical and Engineering Sciences in Medicine, 43(3), 735-738.

Horton, J. (2017). The all or nothing problem. The Journal of Philosophy, 114(2), 94-104.

Hosen, I., Al Mamun, F., Sikder, M. T., Abbasi, A. Z., Zou, L., Guo, T., \& Mamun, M. A. (2021). Prevalence and Associated Factors of Problematic Smartphone Use During the COVID-19 Pandemic: A Bangladeshi Study. Risk Management and Healthcare Policy, $14,3797$.

Khan, R. A., \& Jawaid, M. (2020). Technology enhanced assessment (TEA) in COVID 19 pandemic. Pakistan Journal of Medical Sciences, 36(COVID19-S4), S108.

Lurie, N., Saville, M., Hatchett, R., \& Halton, J. (2020). Developing Covid-19 vaccines at pandemic speed. New England Journal of Medicine, 382(21), 1969-1973.

Mason, J. (2016). When is a problem...?"When" is actually the problem! In Posing and solving mathematical problems (pp. 263-285). Springer.

Muthukrishna, M., \& Henrich, J. (2019). A problem in theory. Nature Human Behaviour, 3(3), 221-229.

Nadiahan, M. B. \& Cabauatan, L. I. (2021). Practically ingenious teaching: instructional behavior of teacher education faculty members in a Philippine public state university amidst covid19 pandemic. International Journal of Education, Technology and Science 1(4), 102-118.

Nolan, R. (2021). 'We are all in this together!'Covid-19 and The Lie of Solidarity. Irish Journal of Sociology, 29(1), 102-106.

Oakland, T., \& Iliescu, D. (2016). Ethical standards, guidelines, and related issues pertinent to international testing and assessment. Oxford University Press.
Pfeiffer, L., \& Bayen, T. (2019). Second-order analysis for the time crisis problem. ArXiv Preprint ArXiv:1902.05290.

Purwadi, P., Saputra, W. N. E., Wahyudi, A., Supriyanto, A., Muyana, S., Rohmadheny, P. S., Ariyanto, R. D., \& Kurniawan, S. J. (2021). Student Perceptions of Online Learning during the COVID-19 Pandemic in Indonesia: A Study of Phenomenology. Student Perceptions of Online Learning during the COVID19 Pandemic in Indonesia: A Study of Phenomenology, 10(3), 1515-1528. https://doi.org/10.12973/eu-jer.10.3.1515

Saputra, W. N. E., Alhadi, S., Supriyanto, A., \& Adiputra, S. (2021). The Development of Creative Cognitive-Behavior Counseling Model as a Strategy to Improve Self-Regulated Learning of Student. International Journal of Instruction, 14(2), 627-646. https://doi.org/10.29333/iji.2021.14235a

Saputra, W. N. E., Mappiare-AT, A., Hidayah, N., \& Ramli, M. (2021). KH Ahmad Dahlan's the values of peace in the novel entitled Sang Pencerah: A hermeneutics study. Pegem Journal of Education and Instruction, 11(2), 32-42. https://doi. org/10.14527/pegegog.2021.04

Saputra, W. N. E., Supriyanto, A., Astuti, B., Ayriza, Y., \& Adiputra, S. (2020). The Effect of Student Perception of Negative School Climate on Poor Academic Performance of Students in Indonesia. International Journal of Learning, Teaching and Educational Research, 19(2), 279-291. https://doi.org/10.26803/ ijlter.19.2.17

Savage, M. J., James, R., Magistro, D., Donaldson, J., Healy, L. C., Nevill, M., \& Hennis, P. J. (2020). Mental health and movement behaviour during the COVID-19 pandemic in UK university students: Prospective cohort study. Mental Health and Physical Activity, 19, 100357.

Skegg, D., Gluckman, P., Boulton, G., Hackmann, H., Karim, S. S. A., Piot, P., \& Woopen, C. (2021). Future scenarios for the COVID19 pandemic. The Lancet, 397(10276), 777-778.

Son, C., Hegde, S., Smith, A., Wang, X., \& Sasangohar, F. (2020). Effects of COVID-19 on college students' mental health in the United States: Interview survey study. Journal of Medical Internet Research, 22(9), e21279.

Supriyanto, A., Hartini, S., Irdasari, W. N., Miftahul, A., Oktapiana, S., \& Mumpuni, S. D. (2020). Teacher professional quality: Counselling services with technology in Pandemic Covid-19. Counsellia: Jurnal Bimbingan Dan Konseling, 10(2), $176-189$.

Tria, J. Z. (2020). The COVID-19 pandemic through the lens of education in the Philippines: The new normal. International Journal of Pedagogical Development and Lifelong Learning, $1(1), 2-4$.

Wahid, R., Pribadi, F., \& Wakas, B. E. (2020). Digital Activism: Covid-19 Effects in Campus Learning. Budapest International Research and Critics in Linguistics and Education (BirLE) Journal, 3(3), 1336-1342.

Wahyuni, S. (2016). Assessment dalam Bimbingan dan Konseling. Hikmah, 10(2).

Yusuf, N. (2021). The Effect of Online Tutoring Applications on Student Learning Outcomes during the COVID-19 Pandemic. ITALIENISCH, 11(2), 81-88.

Zizek, S. (2020). PANDEMIC!: Covid-19 Shakes the World. John Wiley \& Sons. 